\title{
GOPHER SNAKE SEARCHING CLIFF SWALLOW NESTS IN EAST CENTRAL UTAH
}

\author{
Nicholas J. Czaplewski1 ${ }^{1}$, Kent S. Smith², John Johnson², Crystal Dockery²,
} Brandon Mason ${ }^{2}$, and Ian D. Browne ${ }^{2}$

ABSTRACT.-We report details of a serendipitous encounter in July 2010 with a gopher snake (Pituophis catenifer) hunting in the mud nests of Cliff Swallows (Petrochelidon pyrrhonota). The swallow nests occurred beneath a deeply overhung sandstone cliff ledge in a box canyon of Ferron Creek in the shale deserts near Ferron, Emery County, Utah. The inaccessibility of the nests and the movement of the snake to and through them attest to both the extraordinary climbing ability of the gopher snake and the nest site selection and nest construction ability of the swallows.

Resumen.-Se presenta los detalles de un encuentro fortuito con una serpiente gófer Pituophis catenifer caza en los nidos de barro de las golondrinas de acantilados Petrochelidon pyrrhonota. Los nidos de golondrina se produjo debajo de una cornisa de piedra arenisca en un acantilado en un cañón de Ferron Creek en el desierto cerca de la Ferron, del condado de Emery, Utah, en julio de 2010. La inaccesibilidad de los nidos y el movimiento de la serpiente ya través de ellos da fe de la extraordinaria capacidad de escalar de la serpiente y la selección de nidos in situ y la capacidad de construcción de las golondrinas.

Snakes are surprisingly agile at climbing, even on vertical substrates, and are known to climb trees and rocks in order to prey occasionally upon birds and their eggs or nestlings (Gans 1962, Blem 1979, Brown and Brown 1987). Among these snakes, the gopher snake Pituophis catenifer (Colubridae) is recognized as an adept climber and a predator on Cliff Swallow nest colonies in the Great Plains and the Pacific Northwest of North America (Thompson and Turner 1980, Brown and Brown 1996). Although these behaviors might be expected wherever the snakes and birds coexist, incidents are uncommonly observed and have not been reported previously in arid southwestern North America. We report an instance of a gopher snake climbing through nests and presumably preying upon, or intending to prey upon, Cliff Swallows or their young under ledge overhangs in a small canyon in central Utah.

On 1 July 2010, Dale Harber, a geologist for the USDA Forest Service, led Native Explorers - a group of students, staff, and facultyto a site on Bureau of Land Management property to observe petroglyphs and pictographs. The artwork was pecked and painted on the canyon rim and cliff walls along Ferron Creek in "The Box," a portion of lower Ferron Canyon about $10 \mathrm{~km}$ east of Ferron, Emery County, Utah (Fig. 1).

Ferron Creek descends the eastern side of the Wasatch Plateau near the western edge of the Colorado Plateau physiographic province. It is a tributary of the San Raphael River, which flows into the Colorado River. Ferron Creek incises "The Box" of Ferron Canyon, revealing yellowish-buff, resistant sandstone of the Mancos Shale Formation at the rims of the canyon and softer gray shale at the base of the cliffs. The creek meanders through the flat-bottomed and relatively short, shallow box canyon formed between the sandstone and shale rims $\left(39^{\circ} 6.2^{\prime} \mathrm{N}\right.$, $11^{\circ} 12.1^{\prime} \mathrm{W}, \mathrm{NAD} 27$ datum; elevation $1710 \mathrm{~m}$ ). Based on the level III and IV ecoregions of the United States, the area occurs within the Shale Deserts subregion (20b) of the Colorado Plateaus ecoregion (Woods et al. 2001). Vegetation of the area is desert riparian adjacent to the creek, arid shrubland on the canyon floor and adjacent upland above the rims. Plants noted in the area along the creek and on the canyon floor included Phragmites communis (carrizo or reed), Tamarix sp. (tamarisk/saltcedar), Elaeagnus angustifolia (Russian olive), Equisetum sp. (scouring rush/horsetail), Ericameria nauseosa (rabbitbrush), Asclepias speciosa (showy milkweed),

${ }^{1}$ Sam Noble Oklahoma Museum of Natural History, 2401 Chautauqua Avenue, University of Oklahoma, Norman, OK 73072. E-mail: nczaplewski@ou.edu ${ }^{2}$ Oklahoma State University Center for Health Sciences, Department of Anatomy and Cell Biology, 1111 W. 17th Street, Tulsa, OK 74107. 


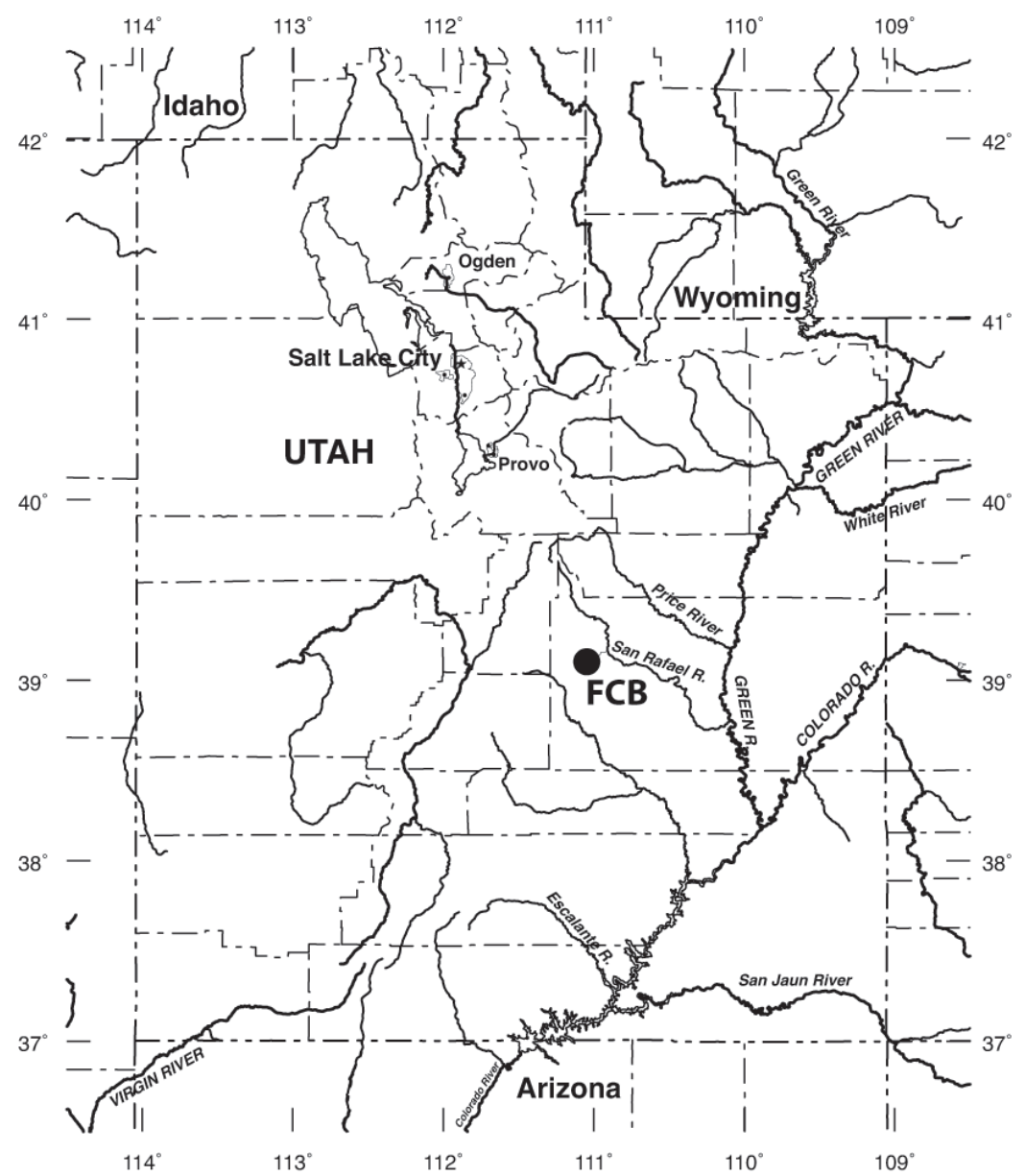

$0 \quad 100 \mathrm{KM}$

Fig. 1. Location of Ferron Creek box canyon (dot labeled FCB), near Ferron, Emery County, Utah, where the swallows' nests and gopher snake were observed in July 2010.

Sarcobatus vermiculatus (greasewood), Artemisia tridentata (big sagebrush), Opuntia sp. (pricklypear cactus), and others. On the canyon rims and adjacent upland, the predominant plants included Artemisia small sp. (sagebrush), Gutierrezia sp. (snakeweed), Atriplex confertifolia (shadscale), Achnatherum (formerly Oryzopsis) hymenoides (Indian ricegrass), Hesperostipa sp. (needle and thread grass), other grasses, Nicotiana sp. (wild tobacco), Opuntia sp., Leucelene ericoides (sand aster), Amelanchier sp. (serviceberry), Juniperus osteosperma (Utah juniper) on rocky breaks and ledges, Eriogonum inflatum (desert trumpet), Eriogonum sp. (buckwheat), and Allium sp. (wild onion).

Numerous Cliff Swallows (Petrochelidon pyrrhonota, Hirundinidae) circled around the cliffs, where they had built many mud nests beneath overhangs of blocky, tabular rock ledges in the cliff walls (Fig. 2A). After observing several pictographs, we were about to ascend the rocky slope from the canyon floor to the mesa above when one member of the group ( JJ) noticed a gopher snake (Pituophis catenifer, Colubridae) overhead in some of the swallow nests (Fig. 2B). At 4:23 PM MDT, the snake had its midbody 


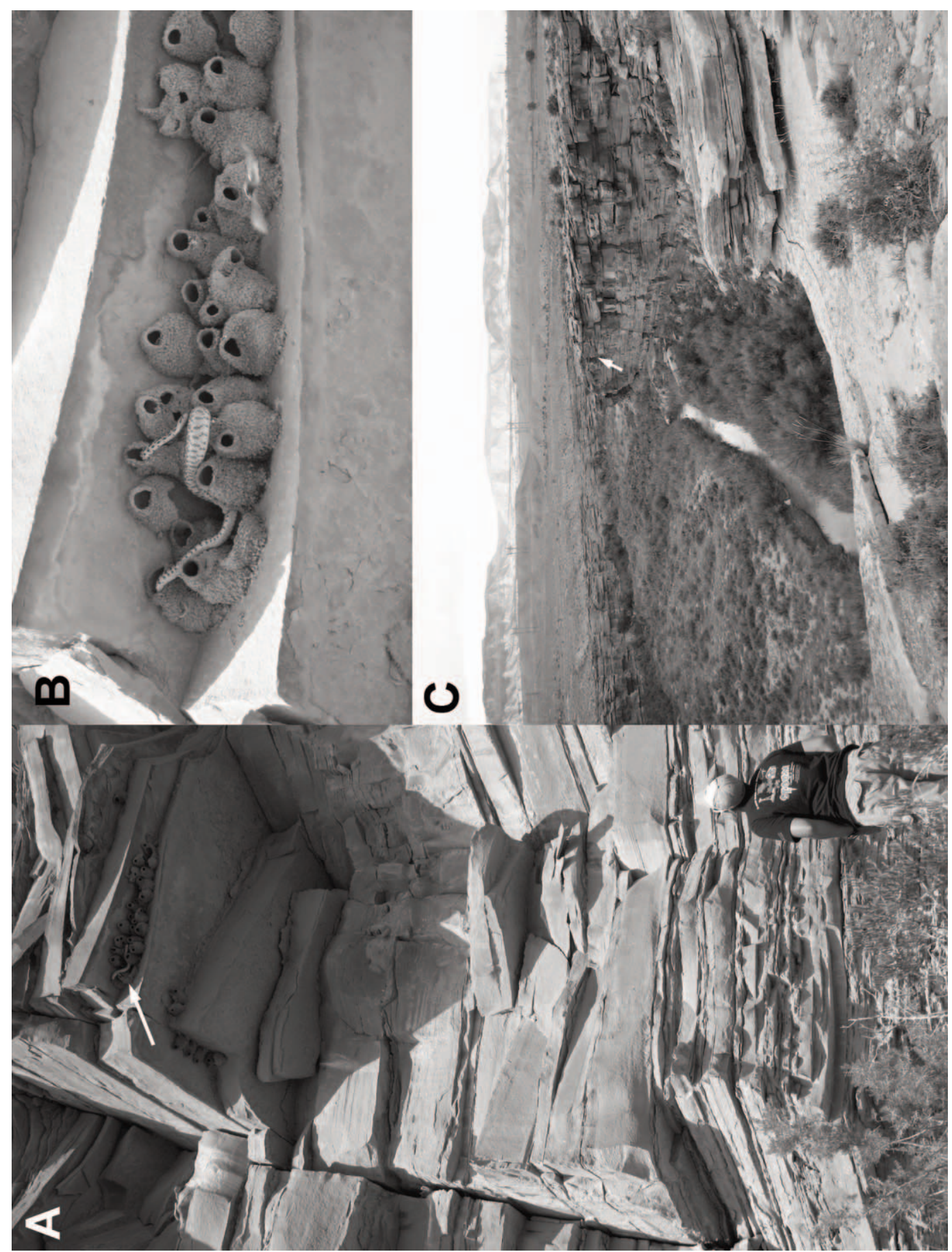

Fig. 2. Photographs documenting searching of Cliff Swallow nests by a gopher snake (Pituophis catenifer): A, cliff face showing John Johnson at the base and the swallow mud nests and snake (arrow) under the overhang; B, close-up view of gopher snake searching Cliff Swallow mud nests while a Cliff Swallow flies past (note bulge in snake's body below its head); C, position of the swallow nests (arrow) relative to the cliff in the box canyon along lower Ferron Creek. 
partially exposed between swallow nest entrance spouts $30-45 \mathrm{~cm}$ apart, and about $20 \mathrm{~cm}$ of its tail was hanging down from another nest opening. Initially, the snake's head was not visible and remained hidden for about 10 minutes. The mud nests and snake were estimated to be approximately $7.5 \mathrm{~m}$ above the bank of Ferron Creek on which we stood. The snake was intertwined through several mud nests beneath a seemingly inaccessible overhanging block of sandstone with a free fall to the ground at the base of the cliff beneath (Fig. 2A, 2C). Seven of the group (JJ, KSS, Mona Easterling, CD, Dale Harber, IDB, and NJC) observed and repeatedly photographed the snake for 25-30 minutes. After another 10 minutes, the snake showed its head momentarily, flicking its tongue. Its head disappeared a few times before the snake finally came out of the entrance to a mud nest and extended its head and the anterior third of its body horizontally to another nest about $30 \mathrm{~cm}$ away, into which it inserted approximately the anterior half of its body. Although the entire snake was never completely visible, we estimated it to be $1.5-2 \mathrm{~m}$ long and about $5 \mathrm{~cm}$ in diameter at midbody. Air temperature above the canyon rim at the time was $31{ }^{\circ} \mathrm{C}\left(88^{\circ} \mathrm{F}\right)$, with a southerly wind of about $15-30 \mathrm{~km} \cdot \mathrm{h}^{-1}$. The sky was partly to mostly cloudy with cumulus clouds and scattered localized rain showers.

The only other wildlife noted during our brief visit to the canyon was an adult female mule deer on the canyon floor. She was first observed near Ferron Creek before our descent from the east rim into "The Box." The doe quickly fled the local area at our approach.

Cliff Swallows constantly circled and called an alarm overhead as we walked along the box canyon floor and cliffs. A swallow, flying near the snake, is visible in one of the photos (Fig. 2B), but the swallows only occasionally flew near the mud nests being searched by the snake. As the snake moved between nests, a bulge in its body was apparent (Fig. 2B, in the exposed part of the body below its head) that probably resulted from the ingestion of Cliff Swallow eggs or nestlings. The bulge was large enough to accommodate several small prey items. By examining the overhanging block of sandstone and adjacent vertical and horizontal cracks in the rock from the base of the cliff, we determined that the mud nests would have been extremely difficult for the snake to access. The snake must have reached the nests by risky and acrobatic climbing and maneuvering, probably by descending from above and anchoring itself in the rock cracks, suspending a substantial length of its body to the nearest mud nest entrance.

Snakes are known to be excellent climbers despite their lack of limbs. The abundance and local concentration of potential prey (eggs, nestlings, and adult birds) for snakes and other predators, which result from the colonial nesting habits of Cliff Swallows, has important evolutionary implications for both predator and prey (Brown and Brown 1996). The distinctive gourdshaped nests of Cliff Swallows and their placement beneath nearly inaccessible overhangs on vertical cliff faces likely evolved in response to predation. Because Cliff Swallows are unable to fend off an attacking snake, nest inaccessibility is important to limit predation. The swallow strategy also serves as a selective force for climbing ability in snakes.

We thank all the participants of Native Explorers 2010. A special thanks goes to Dale Harber, Manti-La Sal National Forests, USDA Forest Service, who gave very generously of his time and broad knowledge and led us to "The Box" in Ferron Canyon. Fieldwork for Native Explorers was funded by the Whitten-Newman Foundation, to which we express our gratitude. We also thank Patty Smith for her help identifying plants and 2 anonymous reviewers for very helpful comments on the manuscript.

\section{Literature Cited}

BLEM, C.R. 1979. Predation of black rat snakes on a Bank Swallow colony. Wilson Bulletin 91:135-137.

Brown, C.R., AND M.B. Brown. 1987. Group-living in Cliff Swallows as an advantage in avoiding predators. Behavior Ecology and Sociobiology 21:97-107.

1996. Coloniality in the Cliff Swallow: the effect of group size on social behavior. University of Chicago Press, Chicago, IL. 566 pp.

GANS, C. 1962. Terrestrial locomotion without limbs. American Zoologist 2:167-182.

Thompson, B.C., AND C.L. Turner. 1980. Bull snake predation at a Cliff Swallow nest. Murrelet 61:35-36.

Woods, A.J., D.A. Lammers, S.A. Bryce, J.M. OMERniK, R.L. Denton, M. Domeier, and J.A. Comstock. 2001. Ecoregions of Utah [color poster with map, descriptive text, summary tables, and photographs; map scale 1:1,175,000]. U.S. Geological Survey, Reston, VA.

Received 14 April 2011 Accepted 11 November 2011 